\title{
Plant Hormones in Phytoplasma Infected Plants
}

\author{
Marina Dermastia* \\ Department of Biotechnology and Systems Biology, National Institute of Biology, Ljubljana, Slovenia
}

Phytoplasmas are bacterial plant pathogens that need a plant host and an insect vector for their spread and survival. In plants, the physiological responses that phytoplasmas trigger result in symptom development through effects on hormonal, nutritional, and stress signaling pathways, and the interactions between these. In this review, recent advances on the involvement of plant hormones together with their known and deduced roles in plants infected with phytoplasmas are discussed. Several studies have directly, or in many cases indirectly, addressed plant hormone systems in phytoplasma-infected plants. These have provided accumulating evidence that phytoplasmas extensively affect plant hormone pathways. Phytoplasmas thus, with disturbing complex plant hormone networks, suppress plant immunity and modify plant structure, while optimizing their nutrient acquisition and facilitating their colonization of the plants, and their dissemination among plants by their insect vectors.

OPEN ACCESS

Edited by:

Dominik K. Großkinsky, University of Copenhagen, Denmark

Reviewed by:

Rita Musetti,

University of Udine, Italy

Ivo Tosevski,

Institute for Plant Protection and

Environment (IZBIS), Serbia

Wei Wei,

Northeast Area (USDA-ARS), United

States

*Correspondence:

Marina Dermastia

marina.dermastia@nib.si

Specialty section:

This article was submitted to

Plant Microbe Interactions,

a section of the journal

Frontiers in Plant Science

Received: 11 February 2019

Accepted: 28 March 2019

Published: 17 April 2019

Citation:

Dermastia M (2019) Plant Hormones in Phytoplasma Infected Plants.

Front. Plant Sci. 10:477.

doi: 10.3389/fp/s.2019.00477
Keywords: hormone crosstalk, host plant, jasmonic acid, phytoplasma, plant hormone, salicylic acid

\section{INTRODUCTION}

Phytoplasmas are cell wall-less bacteria belonging to the class Mollicutes (Bertaccini and Lee, 2018). Analysis of their genomes suggests that they have developed from Gram-positive bacteria by a process of reductive evolution. Consequently, they are very small in size, they have the smallest genome of any known plant bacteria and they have limited metabolic pathways (Kube et al., 2008, 2012; Oshima et al., 2013; Marcone, 2014). Phytoplasmas thrive and multiply in both plant and hemipteran insect hosts. The wild reservoirs of phytoplasmas, e.g., common alder (Alnus glutinosa) (Maixner and Reinert, 1999), elm (Ulmus spp.) (Katanić et al., 2016; Mehle et al., 2017), or clematis (Clematis vitalba) (Angelini et al., 2004) may exhibit typical symptoms of phytoplasma diseases, but often they remain free from obvious symptoms. However, under specific environmental conditions and with specific insect vectors, phytoplasmas can change the plant host and cause disease. Therefore, several phytoplasmas have been discovered to be pathogens of economically important crops (Bertaccini et al., 2014; Dermastia et al., 2017). With the particular economic importance of phytoplasma diseases, most of available data have been collected from infected crops and plants with a horticultural value, and not by more common ways that use model plants to study their interactions with microbes.

In plants, phytoplasmas exclusively inhabit the phloem tissues. As they have an obligatory parasitic lifestyle, it is still not possible to grow them routinely under in vitro conditions (Contaldo et al., 2012, 2016). Consequently, our knowledge of their biology is fragmented, and in most cases it remains indirect, as deduced from the known genome sequences of a few phytoplasmas (Shigeyuki and Yasuko, 2015) and/or from transcriptomic, proteomic, and metabolomic studies of the diseased plants (Ehya et al., 2013; Abbà et al., 2014; Gai et al., 2014b, 2018b; Liu et al., 2014; Luge et al., 2014; Fan et al., 2015a,b,c, 2017; Mardi et al., 2015; Nejat et al., 2015; Dong et al., 2016; Dermastia, 2017; Snyman et al., 2017; Wang et al., 2018). 
Initially phytoplasma diseases were classified as auxonic, which means affecting the plant host growth (Horsfall and Dimond, 2012). Now it becomes evident that the pathogenicity of phytoplasmas involves a number of effector proteins, which have profound and diverse effects not only on growth, but also on other aspects of plant life. Phytoplasmas secret their effectors into the cytoplasm of the phloem sieve cells (Bai et al., 2009; Hoshi et al., 2009; MacLean et al., 2011, 2014; Sugio et al., 2011b; Anabestani et al., 2017; Kitazawa et al., 2017). In the cells where they finally unload from the phloem, these effector proteins trigger physiological responses in the plant that result in symptom development. Infected plants can show different symptoms, including proliferation of shoots (i.e., witches' broom), stunting, yellowing, formation of leaf-like tissues instead of flowers (i.e., phyllody), and greening of the floral organs (i.e., virescence). Such physiological conditions appear to be a consequence of phytoplasma effects on hormonal, nutritional, and both, developmental and stress signaling pathways, and the interactions between these.

It has already been shown that most phytoplasma-induced symptoms mirror alterations in gene expression and/or changed protein levels in infected plants, as compared to uninfected plants. Several of these changes are related to genes associated with the expression of hormones. Plant hormones are naturally occurring, small, organic molecules that have important regulatory roles in plant growth and developmental processes (Rijavec and Dermastia, 2010; Wasternack and Song, 2016; Liu et al., 2017; Ahanger et al., 2018; Binenbaum et al., 2018; Camara et al., 2018; Ma et al., 2018; Skalický et al., 2018; Weijers et al., 2018; Wasternack and Strnad, 2019). They are also involved in plant defense responses against pathogens (Pieterse et al., 2012; Shigenaga and Argueso, 2016; Shigenaga et al., 2017). Plant hormones act through complex networks of interactions, referred to as the hormone crosstalk, which results in changes to the plant physiology, including plant immunity (Kohli et al., 2013). The key plant hormones involved in plant immunity are salicylic acid (SA), jasmonic acid (JA) and ethylene. Other hormones, however less studied, are also important parts of plant defense signaling pathways, such as abscisic acid, auxins, gibberellic acid, cytokinins, brassinosteroids, and peptide hormones (Bari and Jones, 2009; Shigenaga and Argueso, 2016; Shigenaga et al., 2017). Their roles appear to be in the fine tuning of responses to pathogens through activation of the specific physiological processes that are required to defend a plant against invading organisms (Shigenaga and Argueso, 2016).

Due to several limitations associated with phytoplasma research, few studies have directly addressed the levels of plant hormones in phytoplasma-infected plants (e.g., Lazar, 2010; Sugio et al., 2011a, 2014; Gai et al., 2014b; Luge et al., 2014; Minato et al., 2014; Paolacci et al., 2017). However, there are several indirect indications of the involvement of plant hormones in phytoplasma-plant interactions. Of note, the studies that suggest the plant hormone contribution to pathogenesis are very diverse. The analyses were performed on different parts of plants, e.g., whole leaves (Gai et al., 2014a; Youssef et al., 2018), leaf midribs (Hren et al., 2009; Prezelj et al., 2016a), phloem sap (Gai et al., 2018a); they use different approaches, e.g., direct hormone evaluation (Lazar, 2010) or gene expression analyses (Hren et al., 2009; Musetti et al., 2013; Paolacci et al., 2017); and very different techniques, e.g., HPLC analysis (Youssef et al., 2018), microarray data or real-time PCR analyses (Hren et al., 2009), or RNA-seq data analysis (Snyman et al., 2017). Taking this into account, the results of these studies are not directly comparable.

Here, the involvement of plant hormones together with their known and deduced roles in plants infected with phytoplasmas (Table 1) are reviewed and discussed.

\section{SALICYLIC ACID}

In plants, the phenolic hormone SA exists as both a free acid and in conjugated forms that result from its glucosylation, hydroxylation, and methylation (Lee et al., 1995). The major conjugate is usually SA 2-O-glucopyranosyl (syn. SA 2-O- $\beta$ D-glucoside, https://pubchem.ncbi.nlm.nih.gov/compound/ 151505\#section=Synonyms). SA was the first of the plant hormones for which a role in plant defense against pathogens was shown (White, 1979). It is involved in local defense systems against biotrophic and hemibiotrophic pathogens, as well as in systemic acquired resistance (Fu and Dong, 2013). NONEXPRESSOR OF PATHOGENESIS RELATED PROTEIN 1 (NPR1) and its paralogs, NPR3, and NPR4, have been proposed as SA receptors (Fu et al., 2012; Wu et al., 2012). NPR1 regulates gene expression by physically interacting with TGA transcription factors. These bind to the promoters of the PATHOGENESIS RELATED (PR) PROTEIN genes, the expression of which is thus activated in the presence of SA (Fu and Dong, 2013). Among the several PR genes that encode PR proteins (van Loon et al., 2006), PR-1, PR-2, and PR-5 are induced by SA and are commonly used as molecular markers for the SA-dependent systemic acquired resistance signaling (Frías et al., 2013; Fu and Dong, 2013).

\section{Effects of Phytoplasma Infection on Salicylic Acid Biosynthesis and Signaling}

Salicylic acid studies have revealed that several salicylate biosynthetic genes are up-regulated in the midribs or whole leaves of grapevine infected with the phytoplasma ' $\mathrm{Ca}$. P. solani', e.g., VvICS, which encodes isochorismate synthase, and VvSamt, which encodes S-adenosyl-L-methionine: salicylic acid carboxyl methyltransferase, which catalyzes the formation of the volatile ester methyl salicylate from SA (Hren et al., 2009; Dermastia et al., 2015; Paolacci et al., 2017; Rotter et al., 2018). In addition, quantification of SA and its conjugates in the main leaf veins during infections of grapevine with ' $\mathrm{Ca}$. P. solani' showed a 26fold increase in SA 2-O-glucopyranosyl (Prezelj et al., 2016b), and significantly higher free and total SA, as compared to uninfected grapevine (Paolacci et al., 2017). Salicylic acid-glucopyranoside and salicylate are also greatly increased in the grapevine main leaf veins infected with the flavescence dorée phytoplasma (Prezelj et al., 2016a).

The relative expression of $V v N P R 1$ is not different across grapevine infected with ' $\mathrm{Ca}$. P. solani', as compared to uninfected plants or plants recovered from this infection. However, a small up-regulation of $V v N P R 1.2$ in symptomatic 
TABLE 1 | Summarized studies on phytoplasma infected plants, which report plant hormones.

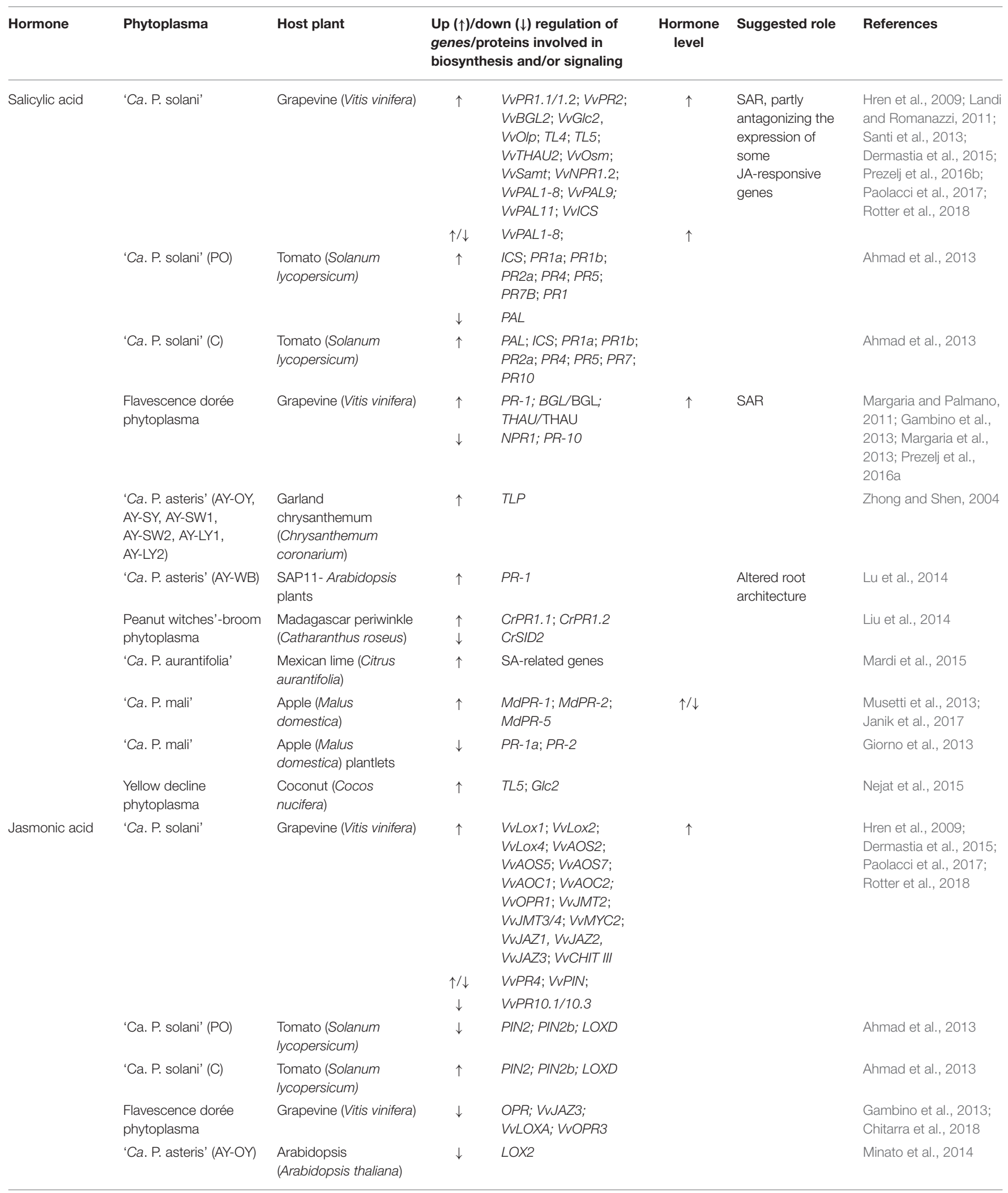


TABLE 1 | Continued

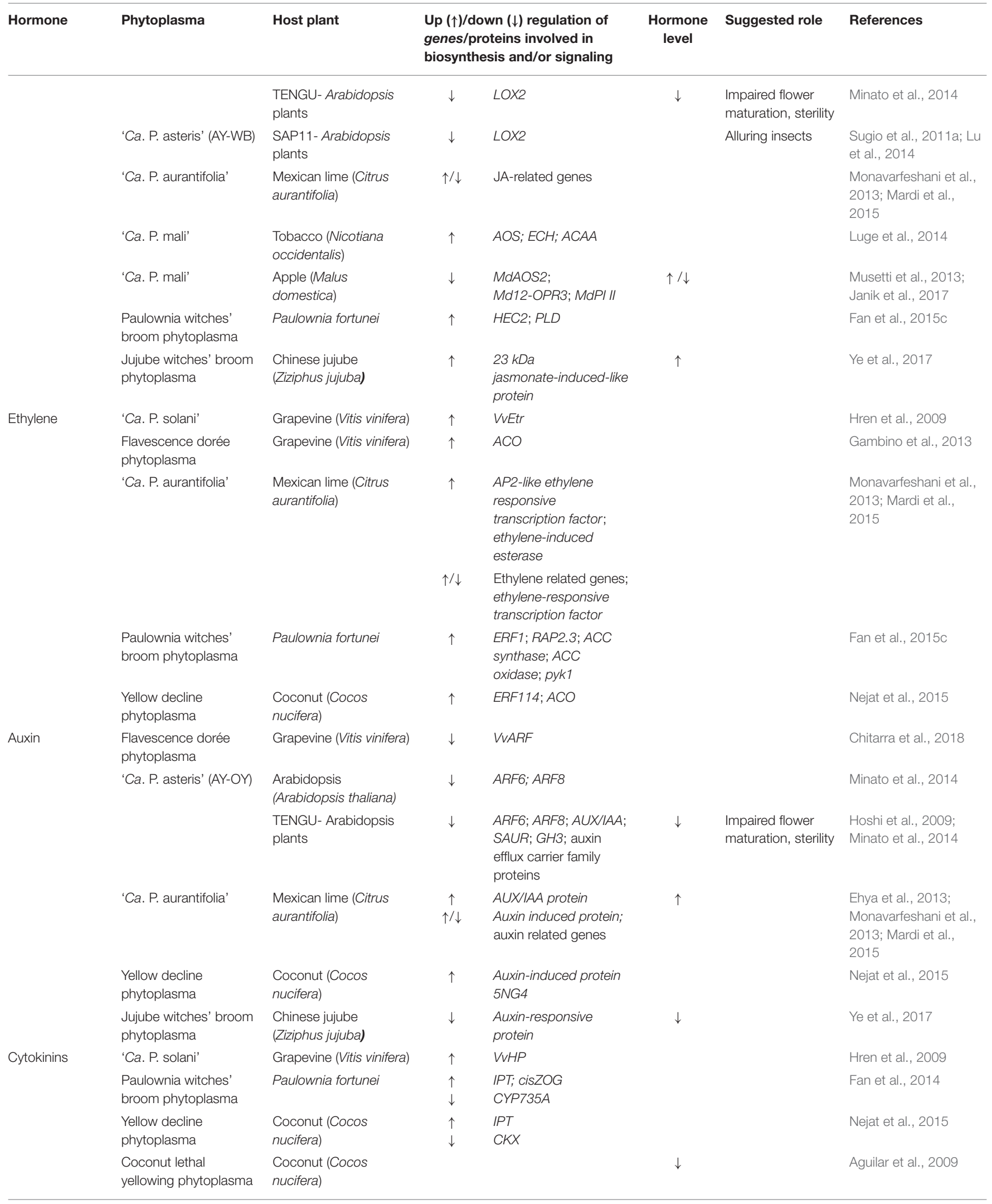


TABLE 1 | Continued

\begin{tabular}{|c|c|c|c|c|c|c|c|}
\hline \multirow[t]{5}{*}{ Hormone } & \multirow{2}{*}{$\begin{array}{l}\text { Phytoplasma } \\
\begin{array}{l}\text { Phytoplasma causing } \\
\text { branching phenotype }\end{array}\end{array}$} & \multirow{2}{*}{$\begin{array}{l}\text { Host plant } \\
\text { Euphorbia pulcherrima }\end{array}$} & \multicolumn{2}{|c|}{$\begin{array}{l}\text { Up }(\uparrow) / \text { down }(\downarrow) \text { regulation of } \\
\text { genes/proteins involved in } \\
\text { biosynthesis and/or signaling }\end{array}$} & \multirow[t]{2}{*}{$\begin{array}{l}\text { Hormone } \\
\text { level }\end{array}$} & \multirow[t]{2}{*}{ Suggested role } & \multirow{2}{*}{$\begin{array}{l}\text { References } \\
\begin{array}{l}\text { Nicolaisen and } \\
\text { Horvath, } 2008\end{array}\end{array}$} \\
\hline & & & $\uparrow$ & AHP1 & & & \\
\hline & Not determined & $\begin{array}{l}\text { Madagascar periwinkle } \\
\text { (Catharantus roseus) }\end{array}$ & & & $\uparrow$ & Virescent flowers & Davey et al., 1981 \\
\hline & $\begin{array}{l}\text { Mulberry yellow dwarf } \\
\text { phytoplasma }\end{array}$ & $\begin{array}{l}\text { Mulberry (Morus } \\
\text { multicaulis) }\end{array}$ & $\begin{array}{l}\uparrow \\
\downarrow\end{array}$ & $\begin{array}{l}\text { IPT } \\
\text { CKX }\end{array}$ & $\uparrow$ & & Gai et al., 2014a \\
\hline & $\begin{array}{l}\text { Phytoplasmas: Faba } \\
\text { bean phyllody; Brinjal } \\
\text { little leaf; Strawberry } \\
\text { green petal }\end{array}$ & $\begin{array}{l}\text { Madagascar periwinkle } \\
\text { (Catharantus roseus) }\end{array}$ & & & $\uparrow / \downarrow$ & & Lazar, 2010 \\
\hline \multirow[t]{4}{*}{ Abscisic acid } & 'Ca. P. aurantifolia' & $\begin{array}{l}\text { Mexican lime (Citrus } \\
\text { aurantifolia) }\end{array}$ & $\uparrow / \downarrow$ & ABA related genes & & & Mardi et al., 2015 \\
\hline & 'Ca. P. mali' & $\begin{array}{l}\text { Apple (Malus } \\
\text { domestica) }\end{array}$ & & & $\uparrow$ & & Janik et al., 2017 \\
\hline & $\begin{array}{l}\text { Paulownia witches' } \\
\text { broom phytoplasma }\end{array}$ & Paulownia fortunei & $\uparrow$ & $P Y L ; A B F$ & & & Fan et al., 2014 \\
\hline & $\begin{array}{l}\text { Mulberry yellow dwarf } \\
\text { phytoplasma }\end{array}$ & $\begin{array}{l}\text { Mulberry (Morus } \\
\text { multicaulis) }\end{array}$ & $\uparrow$ & $\begin{array}{l}\text { zeaxanthin epoxidase; } \\
\text { 9-cis-epoxycarotenoid } \\
\text { dioxygenase }\end{array}$ & $\uparrow$ & & Gai et al., 2014a \\
\hline \multirow[t]{4}{*}{ Gibberellins } & 'Ca. P. aurantifolia' & $\begin{array}{l}\text { Mexican lime (Citrus } \\
\text { aurantifolia) }\end{array}$ & $\uparrow$ & $\begin{array}{l}\text { CPS; KS; KO; KAO; } \\
\text { GA3OX; GA2OXS; } \\
\text { IolO2; casbene } \\
\text { synthase }\end{array}$ & & & Mardi et al., 2015 \\
\hline & $\begin{array}{l}\text { Peanut witches'-broom } \\
\text { phytoplasma }\end{array}$ & $\begin{array}{l}\text { Madagascar periwinkle } \\
\text { (Catharanthus roseus) }\end{array}$ & $\downarrow$ & CrGA1.1 & & & Liu et al., 2014 \\
\hline & $\begin{array}{l}\text { Yellow decline } \\
\text { phytoplasma }\end{array}$ & $\begin{array}{l}\text { Coconut (Cocos } \\
\text { nucifera) }\end{array}$ & $\uparrow$ & GA2OXs & & $\begin{array}{l}\text { Stunting, } \\
\text { inflorescence } \\
\text { necrosis and } \\
\text { premature nut fall }\end{array}$ & Nejat et al., 2015 \\
\hline & $\begin{array}{l}\text { Phytoplasma causing } \\
\text { branching phenotype }\end{array}$ & Euphorbia pulcherrima & $\uparrow$ & GAST-1-like & & $\begin{array}{l}\text { Branching } \\
\text { phenotype }\end{array}$ & $\begin{array}{l}\text { Nicolaisen and } \\
\text { Horvath, } 2008\end{array}$ \\
\hline Brassinosteroids & 'Ca. P. aurantifolia' & $\begin{array}{l}\text { Mexican lime (Citrus } \\
\text { aurantifolia) }\end{array}$ & $\downarrow$ & $\mathrm{BA}$ related genes & & & $\begin{array}{l}\text { Ehya et al., 2013; Mardi } \\
\text { et al., } 2015\end{array}$ \\
\hline
\end{tabular}

Gene names are taken from the original studies.

leaves was only reported for one growing season. In contrast, the levels of the transcript of another gene involved in SA signaling, $V v E D S 1$, were significantly higher in symptomatic infected grapevine, as compared to uninfected plants. This same study showed that some salicylate responsive genes from the WRKY transcription family are up-regulated in leaves of symptomatic grapevine and of grapevine recovered from the disease bois noir, which is caused by the ' $\mathrm{Ca}$. P. solani' phytoplasma (Paolacci et al., 2017).

\section{The Salicylic Acid Marker PR-Proteins}

More data are available on the expression of genes that encode the SA-signaling marker PR proteins. These are up-regulated in phytoplasma-infected seedlings of garland chrysanthemum (Zhong and Shen, 2004) and in leaf vascular tissues of Mexican lime infected with 'Ca. P. aurantifolia' (Monavarfeshani et al., 2013). Increased expression of the gene that encodes the PR1 protein was shown for mulberry phloem sap infected with phytoplasmas (Gai et al., 2018a).
In Catharanthus roseus flowers infected with peanut witches'broom phytoplasma, a transcriptome profile revealed upregulation of the CrPR1.1 and CrPR1.2 genes (Liu et al., 2014). In grapevine infected with 'Ca. P. solani', expression of $V v P R 1.1 / 1.2$ was increased in leaves as compared to uninfected plants (Paolacci et al., 2017). In addition, increased levels of the leaf transcripts of $V v G L C 2, V v G L C 1$, and $V v G L C 3$ have been shown to be involved in the development of bois noir in grapevine (Hren et al., 2009; Landi and Romanazzi, 2011; Dermastia et al., 2015; Paolacci et al., 2017). These genes encode an isoform of $\beta$-1,3-glucanases, a member of the class $2 \mathrm{PR}$ proteins (PR-2). In addition, their expression (Gambino et al., 2013) together with high levels of the $\beta$-1,3-glucanase protein product have been demonstrated in the grapevine leaves infected with the flavescence dorée phytoplasma (Gambino et al., 2013). There is also an increase in the leaf transcript levels of genes from the PR-5 class upon infection with ' $\mathrm{Ca}$. P. solani' (Hren et al., 2009; Santi et al., 2013; Dermastia et al., 2015; Paolacci et al., 2017; Rotter et al., 2018) and for the phytoplasma 
that causes flavescence dorée (Margaria and Palmano, 2011; Gambino et al., 2013; Margaria et al., 2013; Prezelj et al., 2016a). Of further interest, an association between PR-5 gene expression and susceptibility of a grapevine cultivars has been reported, whereby $P R-5$ leaf transcript levels were higher in less susceptible grapevine cultivars (Margaria and Palmano, 2011; Prezelj et al., 2016a).

Increased expression of $P R-1 a, P R-2 a$ and $P R-5$ as compared to uninfected plants was shown in leaves after infection of tomato with the ' $\mathrm{Ca}$. P. solani' strains PO and C (Ahmad et al., 2013), and for apple tree infected with 'Ca. P. mali' (Musetti et al., 2013). Expression of $P R-5$ and $P R-2$ were also increased in coconut leaves infected with yellow decline phytoplasma (Nejat et al., 2015).

For mulberry phloem sap infected with phytoplasmas, induced expression of MuMLPL329 was seen, which encodes major latex protein-like 329. Ectopic expression of this gene enhances mulberry resistance to several pathogens, including phytoplasmas. Although treatment of wild-type mulberry seedlings with SA did not affect MuMLPL329 expression, the $P R-2$ and $P R-5$ genes were highly expressed in $M u M L P L 329-$ overexpressing transgenic Arabidopsis plants (Gai et al., 2018a).

Of note, in contrast to field grown plants, in in vitro micropropagated apple plantlets infected with ' $\mathrm{Ca}$. P. mali', the relative expression levels of $P R-1 a$ and $P R-2$ were lower than in uninfected plants, while expression of the gene that encodes the thaumatin-like protein from the PR-5 group was not changed. On the other hand, up-regulation of $P R-6$ and $P R-8$ was observed in these infected apple plantlets (Giorno et al., 2013).

\section{The DMR6 Susceptibility Gene}

The DMR6 (downy mildew resistance 6) gene encodes an oxidoreductase (2-oxoglutarate (2OG)-Fe(II) oxygenase) (Van Damme et al., 2005, 2008; Zeilmaker et al., 2015), and this is required for susceptibility of Arabidopsis to Hyaloperonospora arabidopsidis, a causal agent of downy mildew in Arabidopsis (Van Damme et al., 2008). The DMR6 protein has recently been functionally characterized as SA 5-hydroxylase, which catalyzes the formation of 2,5-dihydroxybenzoic acid in Arabidopsis. This has essential roles in mediation of SA homeostasis during plant development, leaf senescence, and pathogen responses (Zhang et al., 2017). It has been suggested that DMR6 acts as a susceptibility $S$ gene in a class of suppressors of plant immunity (Zeilmaker et al., 2015). The expression levels of a grapevine ortholog of DMR6 that shows $69 \%$ similarity to the sequence of the AtDMR6 gene from Arabidopsis was higher in grapevine plants that were infected with ' $\mathrm{Ca}$. P. solani' and flavescence dorée phytoplasma, as compared to uninfected plants (Prezelj et al., 2016a; Rotter et al., 2018).

\section{The Exogenous Application of SA-Analog}

A treatment of grapevine cuttings exposed to the infectious vector of flavescence dorée phytoplasma Scaphoideus titanus with a functional analog of SA, acibenzolar-S-methyl, reduced the rate of infected plants, but was ineffective in inducing recovery from disease under field conditions (Miliordos et al., 2017).

\section{JASMONIC ACID}

Jasmonic acid and its derivatives are lipid-derived signaling compounds that are formed through the lipoxygenase pathway from the $\alpha$-linolenic acid of chloroplast membranes. JA is a major plant hormone that is involved in stress responses, such as insect attack, wounding, drought, and attack by necrotrophic pathogens (Yan and Xie, 2015). JA is also a signal in several developmental processes (Wasternack, 2015; Wasternack and Song, 2016). In addition, recent studies have shown that some microbes avoid host plant defense systems to promote host susceptibility through hijacking of the JA pathway (Yan and Xie, 2015).

\section{Effects of Phytoplasma Infection on Jasmonic Acid Biosynthesis and Signaling}

In grapevine leaves infected with 'Ca. P. solani', most jasmonate biosynthetic genes show up-regulation, as compared to uninfected plants (Paolacci et al., 2017). Specifically, among the four $V v L O X$ genes that encode lipoxygenases, the transcripts of two were significantly higher in symptomatic and nonsymptomatic leaves, as well as in the leaves of grapevine recovered from bois noir. The other two $V v L O X$ genes were significantly up-regulated only in the leaves of non-symptomatic and recovered plants. In contrast, in other studies with the same grapevine cultivar infected with ' $\mathrm{Ca}$. P. solani', the $V v L O X$ genes were significantly up-regulated in symptomatic leaves (Hren et al., 2009; Dermastia et al., 2015; Rotter et al., 2018), but not in leaves of the recovered plants (Dermastia et al., 2015). In this pathosystem, it has been shown that expression of several genes that encode allene oxide synthase and allene oxide cyclase involved in JA biosynthesis (Wasternack and Strnad, 2019) depends on the period of the growing season, as well as the disease status (Paolacci et al., 2017). As compared to uninfected plants, the VvOPR1 gene, which encodes 12- oxo-phytodienoic acid reductase, and the VvJMT2 and VvJMT3/4 genes, which encode jasmonate-O-methyltransferase, are up-regulated in leaves of infected and recovered plants. In agreement with the increased expression of VvJMT2 and VvJMT3/4 in these plants, the levels of methyl-jasmonate were also significantly higher. In the JA signaling pathway, the gene that encodes transcription factor MYC2 was up-regulated, as also seen for some of the genes that encode the jasmonate ZIM-domain genes proteins (JAZ). In addition, it has been shown that some of the genes that encode jasmonate-inducible WRKY transcription factors are slightly down-regulated in leaves of symptomatic plants, as compared to those of recovered and uninfected plants.

The genes that encode allene oxide synthase 2, oxophytodienoate reductase and JA-inducible proteinase inhibitor II were up-regulated in apple tree leaves following recovery from infection with ' $\mathrm{Ca}$. P. mali', as compared to diseased plants (Musetti et al., 2013). Tobacco infected with the 'Ca. P. mali' strain AT showed up-regulation of $\alpha$-linolenic acid metabolism in leaf veins, which is consistent with increased JA levels (Luge et al., 2014). On the contrary, in leaves of Mexican lime infected with ' $C a$. P. aurantifolia' the LOX1 and AOS genes, and the genes that encode the JAZ protein that inhibits 
the expression of JA-responsive genes, were down-regulated. However, JMT gene expression was increased in response to phytoplasma infection (Mardi et al., 2015).

Transcriptomic analysis of mulberry phloem sap infected with phytoplasmas showed differential expression of several mRNAs associated with JA metabolism and signaling (Gai et al., 2018a). In leaves of Chinese jujube in an earlier stage after infection of phytoplasma causing jujube witches' broom, there were large changes in a JA-induced protein-like gene transcript. Associated with this, the JA levels were increased in the early stages of infection. However, later on, up-regulation of this gene decreased, and that of the gene that encodes the linoleate 13Slipoxygenase 2-like protein showed a more than 6-fold decrease (Ye et al., 2017).

In transgenic Arabidopsis plants that constitutively expressed the phytoplasma virulence effector peptide TENGU, which was first identified in the ' $\mathrm{Ca}$. P. asteris' strain AY-OY and is known to induce dwarfism (Hoshi et al., 2009), JA levels were decreased (Minato et al., 2014). Arabidopsis plants infected with the ' $\mathrm{Ca}$. P. asteris' strain AY-WB in general produce less JA in young leaves as compared to old leaves and uninfected plants (Sugio et al., 2011a). Additionally, it was shown in the same study that binding of the phytoplasma effector SAP11 destabilized the CINCINNATA-related TEOSINTE BRANCHED1/CYCLOIDEA/PROLIFERATING CELL FACTORS (CIN-TCP) 1 and 2 transcription factors, which control plant development and promote expression of the LOX genes. Consequently, SAP11-mediated destabilization of CIN-TCP resulted in down-regulation of $L O X$ genes and JA synthesis, and an increase in a progeny of the AY-WB insect vectors. In apple tree during an infection with ' $\mathrm{Ca}$. P. mali', the binding of TCP transcription factors to the SAP11like effector ATP_00189 was associated with higher levels of 7-iso-jasmonyl- $L$-isoleucine and cis-12-oxo-phytodienoic acid in spring, when the phytoplasmas were not found in the canopy. Their accumulation was not induced further up to the end of the growing season. On the other hand, in uninfected trees the levels of both of these compounds increased from spring to fall. Therefore, in fall the concentration of JA acid-related compounds were lower in infected plants compared to uninfected ones (Janik et al., 2017). A study on grapevine infected with flavescence dorée phytoplasma showed a decrease in $V v T C P$ transcript levels, which in leaf midribs occurs in parallel with reductions in VvLOXA and VvOPR3 expression (Chitarra et al., 2018).

\section{Jasmonic Acid-Responsive Genes}

While JA-responsive PR3 and PR4 were not affected in leaves of symptomatic grapevine infected with ' $C a$. P. solani' and PR6 was repressed, these genes were up-regulated in plants recovered from bois noir (Paolacci et al., 2017). An up-regulation of the PR-6 gene PIN2 was seen in leaves of tomato plants infected with ' $\mathrm{C} a$. P. solani' strain $\mathrm{C}$, although this gene was down-regulated upon infection with strain PO (Ahmad et al., 2013). Up-regulation of the genes that encode PR-3 and PR10 was shown after infection of coconut with yellow decline phytoplasma (Nejat et al., 2015).
In Paulownia fortunei infected with paulownia witches' broom phytoplasma, there was an indirect indication of increased JA biosynthesis and JA signal transduction, as seen by up-regulation of genes that encode phospholipase $\mathrm{D}$ and transcription factor HEC2 in leaves (Fan et al., 2015c).

\section{The Exyogenous Application of Jasmonic Acid}

The expression of the major latex-protein-like gene (MuMLPL329) was increased in the mulberry phloem sap infected with phytoplasmas and after spraying of mulberry leaves with JA solution, suggesting an involvement of JA in pathogenesis. Of note, similar application of SA did not have any effect on the MuMLPL329 expression (Gai et al., 2018a).

\section{ETHYLENE}

Ethylene is a small hydrocarbon gas hormone in plants that controls the development of leaves, flowers, and fruits (Iqbal et al., 2017). In addition, ethylene is considered to be an important component of the plant defense against pathogens (Shigenaga and Argueso, 2016). Ethylene signaling is often in synergy with JA signaling, and it activates expression of some defense genes, which results in increased resistance to pathogens (Glazebrook, 2005; Shigenaga and Argueso, 2016).

Significant differential expression of genes related to ethylene signaling has been reported for Mexican lime infected with ' $\mathrm{Ca}$. P. aurantifolia', including the genes that encode APETALA2/Ethylene (AP2/ERF)-like-responsive transcription factor, ethylene-responsive transcription factor, and ethyleneinduced esterase (Mardi et al., 2015). Similarly, several genes involved in synthesis, degradation, and regulation of ethylene were significantly differentially expressed in leaf midribs of uninfected grapevine and of those infected with ' $\mathrm{Ca}$. P. solani' (Hren et al., 2009). The gene that encodes the last enzyme in ethylene biosynthesis, 1-aminocyclopropane-1carboxylate oxidase, was overexpressed in leaf midribs during the yellow decline phytoplasma-coconut interaction (Nejat et al., 2015). In mulberry infected with phytoplasmas, the micro RNA mul-miR2111a-5p was predicted to target this gene (Gai et al., 2014a). This gene was significantly upregulated in leaves in the response of Paulownia fortunei to infection with paulownia witches' broom phytoplasma together with genes that encode the ethylene receptor, 1aminocyclopropane-1-carboxylate synthase, and AP2/ERF (Fan et al., 2015c). In addition, AP2/ERF-like mRNA was identified as a possible target of miR172 in grapevine infected with 'Ca. P. asteris' (Snyman et al., 2017), Chinese jujube infected with witches'-broom phytoplasma (Shao et al., 2016), and in phytoplasma infected mulberry (Gai et al., 2014a). It was suggested that activated regulatory pathway of miR156SQUAMOSA PROMOTER BINDING PROTEIN LIKE-miR172 may lead to abnormal leaf shape, downward curling of leaves, flower abortion and sterility, and phyllody (Shao et al., 2016; Snyman et al., 2017). 


\section{"THERE ARE MANY MAGIC RINGS IN THIS WORLD... AND NONE OF THEM SHOULD BE USED LIGHTLY" (J. R. R. TOLKIEN, THE LORD OF THE RINGS)}

\section{Auxins}

Indole-3-acetic acid (IAA) is the most abundant and basic auxin native to plant functions. IAA generates the majority of the auxin effects in intact plants, such as stimulation of growth and in responses to gravity or light stimuli. In addition, elevated IAA levels or auxin signaling can also promote disease development in some plant-pathogen interactions (Kunkel and Harper, 2018; Weijers et al., 2018).

An example where IAA levels were significantly increased, as compared to healthy trees, were leaves of phytoplasma-infected Mexican lime (Ehya et al., 2013). On the other hand, in the same pathosystem, two genes encode IAA-amido synthetase, which prevents free IAA accumulation, and these were significantly upregulated (Mardi et al., 2015). In the early stages after infection of Chinese jujube with jujube witches' broom phytoplasma, several genes involved in auxin production and signaling were downregulated, and the auxin content decreased by some 2.5 -fold (Ye et al., 2017).

Infection of Mexican lime with ' $\mathrm{Ca}$. P. aurantifolia' was characterized by induced expression of genes that encode some auxin-responsive proteins from the large SAUR family of proteins, and with increased transcript levels of a gene that encodes an AUX/IAA protein in leaves (Mardi et al., 2015). This protein family is involved in suppression of auxin-responsive genes, through binding to and inactivation of auxin response factors. These are positive regulators of the auxin signaling pathway (Robert-Seilaniantz et al., 2011), and have also been shown to be differentially expressed in Mexican lime upon infection with ' $\mathrm{Ca}$. P. aurantifolia' (Mardi et al., 2015).

The phytoplasma virulence factor TENGU represses transcription of auxin efflux-related and auxin-responsive genes, including auxin response factors ARF6 and ARF8, which results in lower auxin levels and growth inhibition of apical buds in TENGU-transgenic Arabidopsis (Hoshi et al., 2009; Minato et al., 2014).

\section{Exogenous Applications of Auxins}

For shoots of $C$. roseus grown in vitro, treatment with IAA and another auxin, indole-3-butryc acid, induced recovery from phytoplasma infection. While in recovered plants, 'Ca. P. pruni' and ' $\mathrm{Ca}$. P. asteris' were not detected, or were detected only in a second nested PCR, 'Ca. P. solani' instead persisted in plants with induced remission of the symptoms (Curković, 2008). It has been suggested that the pathway that leads to hormonedependent remission of the symptoms differs from that for natural recovery (Leljak-Levanić et al., 2010). Tomato plants infected with Columbia Basin PPT phytoplasma and treated with IAA showed partially restored healthy profiles of certain PPT-responsive proteins suggesting that these proteins may be involved in hormone homeostasis (Ding et al., 2011). A study in which $C$. roseus was sprayed with an auxin concluded that the auxin-promoted resistance is JA independent (Tai et al., 2013).

\section{Cytokinins}

Cytokinins are a major group of plant hormones that are involved in the control of various processes during plant growth and development. Chemically, they are $N^{6}$-substituated adenine derivatives, which include their respective ribotides, ribosides, and glucosides. Interconversions between different cytokinin metabolites represent the transition between active, inactive, storage, and transport forms, and in vivo this process is relatively dynamic and rapid (Rijavec and Dermastia, 2010). Although some symptoms of phytoplasma-infected plants hint at participation of cytokinins, such as with witches' broom, leaf yellowing, fasciations, reports of their involvement in phytoplasma-plant interactions are scarce and mainly indirect.

It has been suggested that the virescent flowers of phytoplasma-infected C. roseus plants are the result of increased levels of cytokinins in flowers (Davey et al., 1981). In C. roseus infected with phytoplasmas that cause faba bean phyllody, brinjal little leaf, and strawberry green petal, increases in biologically active cytokinin ribosides and decreases in the irreversibly inactive end products of cytokinin metabolism, 9-glucosides, were observed, as compared to uninfected plants. However, these increases were more pronounced in infected leaves than infected roots, stems, and flowers. Of note, no differences were seen for the total cytokinin levels between infected and uninfected plants (Lazar, 2010). In mulberry infected with phytoplasmas that cause mulberry yellow dwarf disease, the cytokinin biosynthetic gene encoding isopentenyl transferase was up-regulated in the infected leaves, while the cytokinin biodegradation gene encoding cytokinin oxidase was down-regulated. It was suggested that this might result in higher concentrations of zeatin, zeatin riboside, and isopentenyladenosine in infected leaves and phloem sap compared to those in uninfected ones, and consequently a broken plant hormone balance in the infected mulberry plants (Gai et al., 2014a). In coconut palm infected with coconut lethal yellowing, there were symptoms of lethal yellowing, and the content of free bases, ribosides and 9-glucosides of isopentenyl adenine-type cytokinins were drastically decreased, as compared to uninfected controls (Aguilar et al., 2009).

The infection of coconut with yellow decline phytoplasma resulted in down-regulation of the expression of the gene that encodes cytokinin dehydrogenase in leaf midribs (Nejat et al., 2015). Similarly, the transcript levels of the gene ICYP735A that encodes cytokinin trans-hydroxylase were lower than for uninfected leaves for Paulownia fortunei infected with Paulownia witches' broom phytoplasma (Fan et al., 2014).

Up-regulation of the Ep11 gene was detected in the ornamental plant Euphorbia pulcherrima when infected with phytoplasmas. It has been suggested that Ep11 has a role in a desirable branching phenotype through the loss of apical dominance (Nicolaisen and Horvath, 2008). Ep11 has high similarity to a histidine-containing phosphotransmitter from Arabidopsis that is known to have a key role in the phosphorelay signal transduction pathway from cytokinin histidine kinase receptors to transcriptional response regulators in the nucleus (Sheen, 2002). An ortholog of Ep11 was differentially expressed in grapevine leaf midribs infected with 'Ca. P. solani' (Hren et al., 2009; Rotter et al., 2018). 


\section{Abscisic Acid}

Abscisic acid is a sesquiterpene signaling molecule with an important regulatory role in plant growth, and in seed development and dormancy, as well as in plant-microbe interactions (Lievens et al., 2017).

The concentration of abscisic acid in the leaves of coconut palms infected with coconut lethal yellowing phytoplasma increased during development of lethal yellowing (León et al., 1996). In mulberry infected with phytoplasmas that cause mulberry yellow dwarf disease the zeaxanthin epoxidase and 9-cis-epoxycarotenoid dioxygenase encoding the key enzymes in the synthesis of abscisic acid were up-regulated, while the abscisic acid 8'-hydroxylase involved in degradation of abscisic acid was down-regulated in the infected leaves and phloem sap compared to the uninfected plants. These findings were in agreement with the higher level of abscisic acid in the infected plants (Gai et al., 2014a).

A transcriptome analysis of Chinese jujube leaves and flowers infected with jujube witches' broom phytoplasmas revealed down-regulation of the gene than encodes zeaxanthin epoxidase (Wei et al., 2017). During infection of Paulownia fortune with Paulownia witches' broom phytoplasma, the expression of the genes that encode the abscisic acid receptor PYL and the abscisic acid responsive element binding factor $\mathrm{ABF}$ were up-regulated in leaves (Fan et al., 2014). In C. roseus plants infected with two strains of ' $\mathrm{Ca}$. P. fraxini' there was no association between a decrease of stomatal conductance and the levels of abscisic acid as the main messenger to environmental stresses that promote stomatal closure. Therefore, an alternative mechanism whereby sucrose accumulation in the apoplast of guard cells leads to stomatal closure was proposed (Tan et al., 2001).

\section{Gibberellins and Brassinosteroids}

The gibberellins comprise a large group of diterpenoid carboxylic acids that are ubiquitous in higher plants. Some gibberellins function as plant hormones, to promote organ expansion and developmental changes (Hedden and Thomas, 2012). On the other hand, brassinosteroids are plant polyhydroxylated steroidal hormones that have crucial roles in plant growth, development, and immunity (Tang et al., 2016). Growing evidence has indicated that brassinosteroids regulate the biosynthesis of gibberellins in rice (Tong et al., 2014) and in Arabidopsis (Unterholzner et al., 2015).

Transcriptional profiling of coconut infected with the yellow decline phytoplasma revealed up-regulation of the gene that encodes gibberelin-2-oxidase, which appeared to result in decreased gibberellin levels and development of symptoms of stunting, inflorescence necrosis, and premature nut fall (Nejat et al., 2015). Significant increases in the transcript levels of several genes involved in gibberellin biosynthesis, and significant down-regulation of genes that encode the gibberellin receptors GID1 and the DELLA protein RGL2, were reported in leaves during infection of Mexican lime with ' $C a$. P. aurantifolia' (Mardi et al., 2015). In the same study, several genes related to biosynthesis and signaling of brassinosteroids were up-regulated.

\section{HORMONE CROSSTALK}

There is increasing evidence that to govern plant immunity, plant hormones act interdependently, through complex antagonistic and synergistic interactions. This hormone crosstalk is primarily a consequence of transcriptional and translational co-regulation, and the outcomes of this complex hormone network are changes in plant physiology that result in defense responses against pathogens. However, frequently there is a trade-off between growth and defense. Our current understanding of these interactions is that growth and immunity are tightly co-regulated, and many negative correlations between growth and defense are the result of regulatory crosstalk (Karasov et al., 2017). On the other hand, successful pathogens have developed sophisticated molecular mechanisms to interfere with hormone biosynthesis and/or hormonal signaling pathways (Pieterse et al., 2012).

\section{"One Ring to Rule Them All" (J. R. R. Tolkien, the Lord of the Rings)}

The "master ring" of the plant hormones involved in plant immunity consists of SA, JA, and ethylene (Bari and Jones, 2009; Shigenaga and Argueso, 2016), and tight co-regulation among these hormones is largely conserved across plant species (Karasov et al., 2017). SA is generally involved in activation of defense responses against biotrophic and hemi-biotrophic pathogens, while JA and ethylene are usually associated with defense against necrotrophic pathogens and herbivorous insects. In spite of these mutually antagonistic interactions, there is also evidence of synergistic interactions (van Wees et al., 2000; Mur et al., 2006; Tsuda et al., 2009; Liu et al., 2016; Zhang et al., 2018). It has also been demonstrated recently that during effector-triggered immunity SA and JA both accumulate to high level. Here, the early induction of JA-responsive genes and denovo synthesis of JA that follows SA accumulation is activated through the SA receptors, which promote degradation of the JAZ JA transcriptional repressors (Liu et al., 2016). In addition, multiple hormone mutant analysis suggested that plants have a more robust immune system in which all three of these main hormones contribute to defense. However, in response to a particular pathogen and its style of infection, one hormone sector can have a greater contribution than the others (Tsuda et al., 2009). It seems that participation of other hormones and regulation of the crosstalk between different hormonal pathways during the infection depend on specific host plant-phytoplasma pathosystem (Table 1), as has been previously suggested for any plant-pathogen interaction (Bari and Jones, 2009).

Evidence collected in this review shows that an up-regulation of SA-signaling is involved in most studied interactions between phytoplasmas and host plants (Table 1). It has been suggested, therefore, that the observed increase in SA-signaling might be associated with a systemic acquired resistance (Ahmad et al., 2015; Dermastia et al., 2015; Prezelj et al., 2016a; Rotter et al., 2018). However, there is no indication that activation of the SA-signaling results in conferring resistance against phytoplasma infection.

Growing evidence suggests an ethylene-auxin crosstalk in which growth responses to ethylene are largely dependent 
on auxin (Zemlyanskaya et al., 2018). Although ethyleneauxin imbalance was observed in lethal-yellowing affected coconut palms in an early study of mycoplasma-like organisms (León et al., 1996), an in-depth analysis of ethylene-auxin crosstalk has not been a part of recent studies in phytoplasmaplant interactions.

\section{Phytoplasma Effector Proteins and Hormone Crosstalk}

Pathogens have adopted innovative strategies to manipulate plant defenses that are regulated by hormones. The tactics that have been frequently used by plant pathogens involve disruption of hormone signaling pathways, for example by producing hormones and/or crosstalk via pathogen-derived effectors (Sugio et al., 2011b; Kazan and Lyons, 2014; Kunkel and Harper, 2018). Since phytoplasmas do not have genes for biosynthesis of plant hormones as it is evident from known whole or draft phytoplasma genome sequences, a secretion of effectors is thought to be a mechanism by which phytoplasma affect plant development.

Phytoplasma effectors can be identified by their cleavable signal peptides that are associated with a functional Secdependent phytoplasma pathway (MacLean et al., 2011). Transgenic Arabidopsis plants with stably expressed SAP11, which encode SAP11 of 'C $a$. P. asteris' strain AY-WB, showed suppressed JA synthesis, and JA and SA defense responses (Sugio et al., 2011a; Lu et al., 2014; Tan et al., 2016). It has been shown that SAP11 reduces JA synthesis by destabilizing the class II TCP transcription factors (Sugio et al., 2011a, 2014). The same mode of action has been demonstrated for a SAP11-like effector from 'Ca. P. mali' during infection of apple tree and it was suggested that SAP11-like proteins might be key players in phytoplasmal infection (Janik et al., 2017).

SA-mediated responses are activated in grapevine infected with the flavescence dorée phytoplasma (Gambino et al., 2013; Prezelj et al., 2016a), with concurrent repression of JA (Gambino et al., 2013; Chitarra et al., 2018) and VvARF (Chitarra et al., 2018). The results here suggested that the JA decrease might involve a similar mechanisms to that shown for SAP11, with involvement of VvTCP (Chitarra et al., 2018). Of note, these responses were not enough for induction of resistance against the flavescence dorée phytoplasma. Although the pathogenesis in grapevine infected with the flavescence dorée phytoplasma or 'Ca. P. solani' is very similar in several aspects (Hren et al., 2009; Prezelj et al., 2016a,b; Rotter et al., 2018), it appears that these two differ in these basic defense responses. After infection of grapevine with ' $\mathrm{C}$. P. solani', a synergistic increase in expression of genes associated with SA and JA biosynthesis and metabolism has been shown, as well as for SA and JA metabolites (Hren et al., 2009; Dermastia et al., 2015; Paolacci et al., 2017; Rotter et al., 2018). However, at the moment there are some indications that effectors of ' $\mathrm{Ca}$. P. solani' other than SAP11-like are involved in this interaction (Čepin, 2018), which might induce different plant responses to this phytoplasma. Although the mode of action of different effectors from different strains of ' $\mathrm{Ca}$. P. solani' is not known at the moment, it has been demonstrated that in the pathosystem of tomato with this phytoplasma, the pathogenesis might be phytoplasma-strain dependent, because two strains of 'Ca. P. solani' induced or repressed the genes associated with SA and JA metabolism and signaling, respectively (Ahmad and Eveillard, 2011).

Phytoplasmas depend on insect vectors for their transmission, and thus for their colonization of plants. On this basis, it has been suggested that these insect vectors can exploit phytoplasmas through independently evolved complex tritrophic interactions. The suppressed biosynthesis of JA via phytoplasma effector SAP11 and following disarmed plant defenses might promote insect vector reproduction on more susceptible plants (Kazan and Lyons, 2014; Tomkins et al., 2018). At the moment it is not known if JA repression during grapevine infection with the flavescence dorée phytoplasma is associated with any volatile organic compounds that might have attracted phytoplasma insect vectors, as has been demonstrated in apple tree infected with 'Ca. P. mali' with a SAP11-like effector (Janik et al., 2017). If this was the case, it might at least partially explain the epidemic nature of flavescence dorée disease, which in the presence of its vector Scaphoideus titanus spreads by a factor of 40 per year (Prezelj et al., 2013).

Arabidopsis plants that stably express an effector of a ' $\mathrm{Ca}$. P. asteris' strain AY-OY, TENGU, have significantly lower levels of transcripts of genes that encode auxin response factors ARF6 and ARF8, which regulate floral development in a JA-dependent manner (Minato et al., 2014).

\section{Phytoplasma-Responsive Micro miRNA Expression Leads To Modulated Hormone Signaling}

Some recent studies on phytoplasma-plant pathosystems have confirmed an important role of micro miRNAs in plant response to infection (Ehya et al., 2013; Gai et al., 2014a; Shao et al., 2016; Snyman et al., 2017; Chitarra et al., 2018). The analyses of phytoplasma-responsive miRNAs in grapevine, mulberry, Mexican lime, and Chinese jujube indicate that several miRNA are conserved among these plants. Moreover, miRNA may cooperatively modulate multiple hormone pathways and be involved in development of some symptoms observed in phytoplasma-infected plants.

Most published studies on phytoplasma-responsive miRNA suggest that miRNA-mediated auxin signaling regulates a response of plants to phytoplasmas. In particular, miR160 and miR166 that target for genes, which encode auxin response factors (ARF) from the family of transcription factors, were differentially expressed between uninfected and phytoplasmainfected Mexican lime (Ehya et al., 2013), mulberry (Gai et al., 2014a), Chinese jujube (Shao et al., 2016), and grapevine (Snyman et al., 2017). In addition, the same family of transcription factors was targeted with miR393 in infected Mexican lime and mulberry (Ehya et al., 2013; Gai et al., 2014a), and with miR164 in infected mulberry and Chinese jujube (Gai et al., 2014a; Shao et al., 2016). A down-regulation of miR159 was detected in phytoplasma infected Mexican lime (Ehya et al., 2013), Chinese jujube (Shao et al., 2016), and 
grapevine (Snyman et al., 2017). This microRNA targets for degradation of mRNAs that encode MYB transcription factors and have a role in plant hormone responses by redirecting auxin signal transduction by interacting with the carboxyl termini of ARFs (Zhang et al., 2011). The results of an analysis of phytoplasma-responsive microRNA in grapevine infected with flavescence dorée phytoplasma suggest that the alteration of JA biosynthetic pathway is promoted by tuning TCP by $T C P / m i R 319$ interplay through the downregulation of JAZ3, a target of both miR169 and the novel miC197-5p, and an ARF, target of miR167. Targets of miR167 were also ARFs in Arabidopsis infected with phytoplasma, as well as in TENGUtransgenic Arabidopsis plants (Minato et al., 2014). The system of $A R F / \mathrm{miR} 167$ influence both auxin signaling and JA pathway (Gutierrez et al., 2012; Boer et al., 2014) and it was suggested that the $A R F / \mathrm{miR} 167$ regulation together with detected decrease in JA concentration is the base of the flower alteration in infected plants (Chitarra et al., 2018). In silico analysis followed a detected differential expression of miR159 and miR319 in leaves of grapevine infected with ' $\mathrm{Ca}$. P. asteris' and Chinese jujube infected with witches'-broom phytoplasma predicted that they target a transcriptional activator of gibberellin-dependent alpha-amylase (GAMYB)-like mRNA (Shao et al., 2016; Snyman et al., 2017), which may contribute to deformation of leaves. Regulation of the gibberellin regulatory network has also been predicted for miR167 during the potato infection with potato virus Y (Križnik et al., 2017). In has been shown in other systems that miR159, miR160, miR167, miR169, miR391, and miR393 are also involved in signaling pathway of abscisic acid (Sunkar et al., 2012), suggesting their vital role in plants subjected to stress conditions.

\section{CONCLUSIONS AND PERSPECTIVES}

The biology of phytoplasma and the responses of infected plants to their presence are still largely unknown due to their specific lifestyle, and the difficulties of their maintenance in vitro for performing controlled infections. However, a lot of new information has become available recently, which is supported by new transcriptomic proteomic and metabolomic data from phytoplasma-infected host plants. Moreover, with

\section{REFERENCES}

Abbà, S., Galetto, L., Carle, P., Carrère, S., Delledonne, M., Foissac, $\mathrm{X}$, et al. (2014). RNA-Seq profile of flavescence dorée phytoplasma in grapevine. BMC Genomics 15:1088. doi: 10.1186/1471-2164-1 5-1088

Aguilar, M. L., Espadas, F., Maust, B., and Sáenz, L. (2009). Endogenous cytokinin content in coconut palms affected by lethal yellowing. J. Plant Pathol. 91, 141-146. doi: 10.4454/jpp.v91i1.634

Ahanger, M. A., Ashraf, M., Bajguz, A., and Ahmad, P. (2018). Brassinosteroids regulate growth in plants under stressful environments and crosstalk with other potential phytohormones. J. Plant Growth Regul. 37, 1007-1024. doi: 10.1007/s00344-018-9855-2

Ahmad, J. N., and Eveillard, S. (2011). Study of the expression of defense related protein genes in stolbur C and stolbur PO phytoplasma-infected tomato. Bull. Insectol. 64, S159-S160. a development of different high-throughput techniques, applications of functional genomics technologies to model plants like Arabidopsis or C. roseus, and possibly with a routine cultivation of these intriguing bacteria, we are now at the starting point for eventually revealing the mechanisms, including the hormone crosstalk, by which phytoplasmas manipulate their hosts.

\section{AUTHOR CONTRIBUTIONS}

The author confirms being the sole contributor of this work and has approved it for publication.

\section{FUNDING}

This work was supported by grants from the Slovenian Research Agency: V4-1103, J4-0813, Slovene-Austrian bilateral grant J17151, and Research Program P4-0165.

\section{ACKNOWLEDGMENTS}

The author would like to thank all co-workers from the National Institute of Biology who have contributed over the years to the valuable data from the phytoplasma research included in this review: Drs. Nataša Mehle, Kristina Gruden, Matjaž Hren, Nina Prezelj, Ana Rotter, Andrej Blejec, Petra Nikolić, Ana Lazar, Elizabeth Covington, Polona Kogovšek, Maja Ravnikar, Marko Chersicola, and Tomaž Rijavec. Her special thanks go to Dr. Günter Brader who helped her through the INGRAPA project to uncover at least some of the well-kept secrets of phytoplasma, and for his useful ideas how to improve this manuscript. She would like to express her very great appreciation to Dr. Matt Dickinson for the years-long cooperation, for taking care of some Slovenian students at Nottingham University, and for his valuable and constructive suggestions after critically read this manuscript. Since the phytoplasma community is not extremely large yet, the author can thank personally almost all of the authors of papers cited in this review, and she apologizes to those whose papers have not been included due to the space limitations. She also expresses her gratitude to Dr. Christopher Berrie for his linguistic touch.
Ahmad, J. N., Renaudin, J., and Eveillard, S. (2013). Expression of defence genes in stolbur phytoplasma infected tomatoes, and effect of defence stimulators on disease development. Eur. J. Plant Pathol. 139, 39-51. doi: 10.1007/s10658-013-0361-x

Ahmad, J. N., Renaudin, J., Eveillard, S., Ahmad, J. N., Renaudin, J., and Eveillard, S. (2015). Molecular study of the effect of exogenous phytohormones application in "stolbur" phytoplasma infected tomatoes on disease development. Phytopathog. Mollic. 5, S121-S122. doi: 10.5958/2249-4677.2015.00052.3

Anabestani, A., Izadpanah, K., Abbà, S., Galetto, L., Ghorbani, A., Palmano, S., et al. (2017). Identification of putative effector genes and their transcripts in three strains related to 'Candidatus Phytoplasma aurantifolia.' Microbiol. Res. 199, 57-66. doi: 10.1016/j.micres.2017.03.001

Angelini, E., Squizzato, F., Lucchetta, G., and Borgo, M. (2004). Detection of a phytoplasma associated with grapevine flavescence dorée in Clematis vitalba. Eur. J. Plant Pathol. 110, 193-201. doi: 10.1023/B:EJPP.0000015361.95661.37 
Bai, X., Correa, V. R., Toruño, T. Y., Ammar, E.-D., Kamoun, S., and Hogenhout, S. A. (2009). AY-WB phytoplasma secretes a protein that targets plant cell nuclei. Mol. Plant-Microbe Interact. 22, 18-30. doi: 10.1094/MPMI-22-1-0018

Bari, R., and Jones, J. D. G. (2009). Role of plant hormones in plant defence responses. Plant Mol. Biol. 69, 473-488. doi: 10.1007/s11103-008-9435-0

Bertaccini, A., Duduk, B., Paltrinieri, S., and Ontaldo, N. (2014). Phytoplasmas and phytoplasma diseases: a severe threat to agriculture. Am. J. Plant Sci. 5, 1763-1788. doi: 10.4236/ajps.2014.512191

Bertaccini, A., and Lee, I.-M. (2018). "Phytoplasmas: an update," in Phytoplasmas: Plant Pathogenic Bacteria - I, eds G. P. Rao, A. Beratccini, N. Fiore, and L. W. Liefting (Singapore: Springer Singapore), 1-29. doi: 10.1007/978-981-13-0119-3_1

Binenbaum, J., Weinstain, R., and Shani, E. (2018). Gibberellin localization and transport in plants. Trends Plant Sci. 23, 410-421. doi: 10.1016/J.TPLANTS.2018.02.005

Boer, D. R., Freire-Rios, A., van den Berg, W. A. M., Saaki, T., Manfield, I. W., Kepinski, S., et al. (2014). Structural basis for DNA binding specificity by the auxin-dependent ARF transcription factors. Cell 156, 577-589. doi: 10.1016/j.cell.2013.12.027

Camara, M. C., Vandenberghe, L. P. S., Rodrigues, C., de Oliveira, J., Faulds, C., Bertrand, E., et al. (2018). Current advances in gibberellic acid (GA3) production, patented technologies and potential applications. Planta 248, 1049-1062. doi: 10.1007/s00425-018-2959-x

Chitarra, W., Pagliarani, C., Abbà, S., Boccacci, P., Birello, G., Rossi, M., et al. (2018). miRVIT: a novel miRNA database and its application to uncover Vitis responses to favescence dorée infection. Front. Plant Sci. 9:1034. doi: $10.3389 /$ fpls.2018.01034

Contaldo, N., Bertaccini, A., Paltrinieri, S., Windsor, H. M., and Windsor, G. D. (2012). Axenic culture of plant pathogenic phytoplasmas. Phytopathol. Mediterr. 51, 607-617. doi: 10.14601/Phytopathol_Mediterr-11773

Contaldo, N., Satta, E., Zambon, Y., Paltrinieri, S., and Bertaccini, A. (2016). Development and evaluation of different complex media for phytoplasma isolation and growth. J. Microbiol. Methods 127, 105-110. doi: 10.1016/j.mimet.2016.05.031

Curković, P. M. (2008). Auxin-treatment induces recovery of phytoplasma-infected periwinkle. J. Appl. Microbiol. 105, 1826-1834. doi: $10.1111 / j .1365-2672.2008 .03946 . x$

Čepin, T. (2018). The Effect of Potential 'Candidatus Phytoplasma solani' Effectors on the Plant Phenotype. Master's thesis. Ljubljana: University of Ljubljana. Available online at: https://repozitorij.uni-lj.si/Dokument.php?id=114210\& lang=slv

Davey, J. E., Van Staden, J., and De Leeuw, G. T. N. (1981). Endogenous cytokinin levels and development of flower virescence in Catharanthus roseus infected with mycoplasmas. Physiol. Plant Pathol. 19, 193-200. doi: 10.1016/S0048-4059(81)80021-5

Dermastia, M. (2017). "Interactions between grapevines and grapevine yellows phytoplasmas BN and FD," in Grapevine Yellows Diseases and Their Phytoplasma Agents, eds M. Dermastia, A. Bertaccini, F. Constable, and N. Mehle (Cham: SpringerBriefs in Agriculture, Springer), 47-67. doi: 10.1007/978-3-319-50648-7_3

Dermastia, M., Bertaccini, A., Constable, F., and Mehle, N. (2017). Grapevine Yellows Diseases and Their Phytoplasma Agents: Biology and Detection. Cham: SpringerBriefs in Agriculture.

Dermastia, M., Nikolic, P., Chersicola, M., and Gruden, K. (2015). Transcriptional profiling in infected and recovered grapevine plant responses to 'Candidatus Phytoplasma solani'. Phytopathog. Mollic. 5, S123. doi: $10.5958 / 2249-4677.2015 .00053 .5$

Ding, Y., Wu, W., Wei, W., Davis, R. E., Lee, I.-M., Jomantiene, R., et al. (2011). Effects of exogenous indole-3-acetic acid on proteomic profiles of potato purple top phytoplasma-infected tomato plants. Bull. Insectology 64, S183-S184.

Dong, Y., Deng, M., Zhao, Z., and Fan, G. (2016). Quantitative proteomic and transcriptomic study on autotetraploid paulownia and its diploid parent reveal key metabolic processes associated with paulownia autotetraploidization. Front. Plant Sci. 7:892. doi: 10.3389/fpls.2016.00892

Ehya, F., Monavarfeshani, A., Mohseni Fard, E., Karimi Farsad, L., Khayam Nekouei, M., Mardi, M., et al. (2013). Phytoplasma-responsive microRNAs modulate hormonal, nutritional, and stress signalling pathways in Mexican lime trees. PLoS ONE 8:66372. doi: 10.1371/journal.pone.0066372
Fan, G., Cao, X., Niu, S., Deng, M., Zhao, Z., and Dong, Y. (2015a). Transcriptome, microRNA, and degradome analyses of the gene expression of paulownia with phytoplamsa. BMC Genomics 16:896. doi: 10.1186/s12864-015-2074-3

Fan, G., Dong, Y., Deng, M., Zhao, Z., Niu, S., and Xu, E. (2014). Plant-pathogen interaction, circadian rhythm, and hormone-related gene expression provide indicators of phytoplasma infection in Paulownia fortunei. Int. J. Mol. Sci. 15, 23141-23162. doi: 10.3390/ijms151223141

Fan, G., Niu, S., Xu, T., Deng, M., Zhao, Z., Wang, Y., et al. (2015b). Plantpathogen interaction-related microRNAs and their targets provide indicators of phytoplasma infection in Paulownia tomentosa $\times$ Paulownia fortunei. PLoS ONE 10:e0140590. doi: 10.1371/journal.pone.0140590

Fan, G., Xu, E., Deng, M., Zhao, Z., and Niu, S. (2015c). Phenylpropanoid metabolism, hormone biosynthesis and signal transduction-related genes play crucial roles in the resistance of Paulownia fortunei to paulownia witches' broom phytoplasma infection. Genes Genomics 37, 913-929. doi: 10.1007/s13258-015-0321-2

Fan, X.-P., Liu, W., Qiao, Y.-S., Shang, Y.-J., Wang, G.-P., Tian, X., et al. (2017). Comparative transcriptome analysis of Ziziphus jujuba infected by jujube witches' broom phytoplasmas. Sci. Hortic. 226, 50-58. doi: 10.1016/J.SCIENTA.2017.08.026

Frías, M., Brito, N., and González, C. (2013). The Botrytis cinerea cerato-platanin $\mathrm{BcSpl} 1$ is a potent inducer of systemic acquired resistance (SAR) in tobacco and generates a wave of salicylic acid expanding from the site of application. Mol. Plant Pathol. 14, 191-196. doi: 10.1111/j.1364-3703.2012.00842.x

Fu, Z. Q., and Dong, X. (2013). Systemic acquired resistance: turning local infection into global defense. Annu. Rev. Plant Biol. 64, 839-863. doi: 10.1146/annurev-arplant-042811-105606

Fu, Z. Q., Yan, S., Saleh, A., Wang, W., Ruble, J., Oka, N., et al. (2012). NPR3 and NPR4 are receptors for the immune signal salicylic acid in plants. Nature 486, 228-232. doi: $10.1038 /$ nature11162

Gai, Y.-P., Yuan, S.-S., Liu, Z.-Y., Zhao, H.-N., Liu, Q., Qin, R.-L., et al. (2018a). Integrated phloem sap mRNA and protein expression analysis reveals phytoplasma infection responses in mulberry. Mol. Cell. Proteomics 17, 1702-1719. doi: 10.1074/mcp.RA118.000670

Gai, Y.-P., Zhao, H.-N., Zhao, Y.-N., Zhu, B.-S., Yuan, S.-S., Li, S., et al. (2018b). MiRNA-seq-based profiles of miRNAs in mulberry phloem sap provide insight into the pathogenic mechanisms of mulberry yellow dwarf disease. Sci. Rep. 8:812. doi: 10.1038/s41598-018-19210-7

Gai, Y. P., Han, X. J., Li, Y. Q., Yuan, C. Z., Mo, Y. Y., Guo, F. Y., et al. (2014b). Metabolomic analysis reveals the potential metabolites and pathogenesis involved in mulberry yellow dwarf disease. Plant Cell Environ. 37, 1474-1490. doi: 10.1111/pce.12255

Gai, Y. P., Li, Y.-Q., Guo, F.-Y., Yuan, C.-Z., Mo, Y.-Y., Zhang, H.-L., et al. (2014a). Analysis of phytoplasma-responsive sRNAs provide insight into the pathogenic mechanisms of mulberry yellow dwarf disease. Sci. Rep. 4:5378. doi: $10.1038 /$ srep05378

Gambino, G., Boccacci, P., Margaria, P., Palmano, S., and Gribaudo, I. (2013). Hydrogen peroxide accumulation and transcriptional changes in grapevines recovered from flavescence dorée disease. Phytopathology 103, 776-784. doi: 10.1094/PHYTO-11-12-0309-R

Giorno, F., Guerriero, G., Biagetti, M., Ciccotti, A. M., and Baric, S. (2013). Gene expression and biochemical changes of carbohydrate metabolism in in vitro micro-propagated apple plantlets infected by 'Candidatus Phytoplasma mali'. Plant Physiol. Biochem. 70, 311-317. doi: 10.1016/j.plaphy.2013.05.040

Glazebrook, J. (2005). Contrasting mechanisms of defense against biotrophic and necrotrophic pathogens. Annu. Rev. Phytopathol. 43, 205-227. doi: 10.1146/annurev.phyto.43.040204.135923

Gutierrez, L., Mongelard, G., Floková, K., Păcurar, D. I., Novák, O., Staswick, P., et al. (2012). Auxin controls Arabidopsis adventitious root initiation by regulating jasmonic acid Homeostasis. Plant Cell 24, 2515-2527. doi: $10.1105 /$ tpc. 112.099119

Hedden, P., and Thomas, S. G. (2012). Gibberellin biosynthesis and its regulation. Biochem. J. 444, 11-25. doi: 10.1042/BJ20120245

Horsfall, J. G., and Dimond, A. E. (2012). "The diseased plant," in Plant Pathology V1: The Diseased Plant, ed J. G. Horsfall (New York, NY; London: Academic Press), 12.

Hoshi, A., Oshima, K., Kakizawa, S., Ishii, Y., Ozeki, J., and Hashimoto, M. (2009). A unique virulence factor for proliferation and dwarfism in plants 
identified from a phytopathogenic bacterium. Proc. Natl. Acad. Sci. U.S.A. 106, 6416-6421. doi: 10.1073/pnas.0813038106

Hren, M., Nikolić, P., Rotter, A., Blejec, A., Terrier, N., Ravnikar, M., et al. (2009). "Bois noir" phytoplasma induces significant reprogramming of the leaf transcriptome in the field grown grapevine. BMC Genomics 10:460. doi: 10.1186/1471-2164-10-460

Iqbal, N., Khan, N. A., Ferrante, A., Trivellini, A., Francini, A., and Khan, M. I. R. (2017). Ethylene role in plant growth, development and senescence: interaction with other phytohormones. Front. Plant Sci. 8:475. doi: 10.3389/fpls.2017.00475

Janik, K., Mithöfer, A., Raffeiner, M., Stellmach, H., Hause, B., and Schlink, K. (2017). An effector of apple proliferation phytoplasma targets TCP transcription factors-a generalized virulence strategy of phytoplasma? Mol. Plant Pathol. 18, 435-442. doi: 10.1111/mpp.12409

Karasov, T. L., Chae, E., Herman, J. J., and Bergelson, J. (2017). Mechanisms to mitigate the trade-off between growth and defense. Plant Cell 29, 666-680. doi: $10.1105 /$ tpc. 16.00931

Katanić, Z., Krstin, L., Ježić, M., Zebec, M., and Curković-Perica, M. (2016). Molecular characterisation of elm yellows phytoplasmas in Croatia and their impact on Ulmus spp. Plant Pathol. 65, 1430-1440. doi: 10.1111/ppa.12524

Kazan, K., and Lyons, R. (2014). Intervention of phytohormone pathways by pathogen effectors. Plant Cell 26, 2285-2309. doi: 10.1105/tpc.114.1 25419

Kitazawa, Y., Iwabuchi, N., Himeno, M., Sasano, M., Koinuma, H., Nijo, T., et al. (2017). Phytoplasma-conserved phyllogen proteins induce phyllody across the Plantae by degrading floral MADS domain proteins. J. Exp. Bot. 68, 2799-2811. doi: $10.1093 / \mathrm{jxb} / \mathrm{erx} 158$

Kohli, A., Sreenivasulu, N., Lakshmanan, P., and Kumar, P. P. (2013). The phytohormone crosstalk paradigm takes center stage in understanding how plants respond to abiotic stresses. Plant Cell Rep. 32, 945-957. doi: 10.1007/s00299-013-1461-y

Križnik, M., Petek, M., Dobnik, D., Ramšak, Ž., Baebler, ̌̌., Pollmann, S., et al. (2017). Salicylic acid perturbs sRNA-gibberellin regulatory network in immune response of potato to potato virus Y infection. Front. Plant Sci. 8:2192. doi: $10.3389 /$ fpls.2017.02192

Kube, M., Mitrovic, J., Duduk, B., Rabus, R., and Seemüller, E. (2012). Current view on phytoplasma genomes and encoded metabolism. Sci. World J. 2012, 1-25. doi: 10.1100/2012/185942

Kube, M., Schneider, B., Kuhl, H., Dandekar, T., Heitmann, K., Migdoll, A. M., et al. (2008). The linear chromosome of the plant-pathogenic mycoplasma 'Candidatus Phytoplasma mali'. BMC Genomics 9:306. doi: 10.1186/1471-2164-9-306

Kunkel, B. N., and Harper, C. P. (2018). The roles of auxin during interactions between bacterial plant pathogens and their hosts. J. Exp. Bot. 69, 245-254. doi: $10.1093 / \mathrm{jxb} / \mathrm{erx} 447$

Landi, L., and Romanazzi, G. (2011). Seasonal variation of defense-related gene expression in leaves from bois noir affected and recovered grapevines. J. Agric. Food Chem. 59, 6628-6637. doi: 10.1021/jf104297n

Lazar, A. (2010). Prevalence of Phytoplasmas in UK. Master's thesis. Ljubljana: University of Ljubljana. Available online at: https://plus.cobiss.si/opac7/bib/ 2267471

Lee, H. I., León, J., and Raskin, I. (1995). Biosynthesis and metabolism of salicylic acid. Proc. Natl. Acad. Sci. U.S.A. 92, 4076-4079.

Leljak-Levanić, D., Ježić, M., Cesar, V., Ludwig-Müller, J., Lepeduš, H., Mladinić, M., et al. (2010). Biochemical and epigenetic changes in phytoplasma-recovered periwinkle after indole-3-butyric acid treatment. J. Appl. Microbiol. 109, 2069-2078. doi: 10.1111/j.1365-2672.2010.04837.x

León, R., Sanatamaria, J. M., Alpizar, L., Escamilla, J. A., and Oropeza, C. (1996). Physiological and biochemical changes in shoots of coconut palms affected by lethal yellowing. New Phytol. 134, 227-234. doi: 10.1111/j.1469-8137.1996.tb04627.x

Lievens, L., Pollier, J., Goossens, A., Beyaert, R., and Staal, J. (2017). Abscisic acid as pathogen effector and immune regulator. Front. Plant Sci. 8:587. doi: $10.3389 /$ fpls.2017.00587

Liu, J., Moore, S., Chen, C., and Lindsey, K. (2017). Crosstalk complexities between auxin, cytokinin, and ethylene in Arabidopsis root development: from experiments to systems modeling, and back again. Mol. Plant 10, 1480-1496. doi: 10.1016/J.MOLP.2017.11.002
Liu, L., Sonbol, F.-M., Huot, B., Gu, Y., Withers, J., Mwimba, M., et al. (2016) Salicylic acid receptors activate jasmonic acid signalling through a noncanonical pathway to promote effector-triggered immunity. Nat. Commun. 7:13099. doi: 10.1038/ncomms 13099

Liu, L.-Y. D., Tseng, H.-I., Lin, C.-P., Lin, Y.-Y., Huang, Y.-H., Huang, C.-K., et al. (2014). High-throughput transcriptome analysis for studying the leafy flower transition of Catharanthus roseus induced by peanut witches'-broom phytoplasma infection. Plant Cell Physiol. 55, 942-957. doi: $10.1093 /$ pcp/pcu029

Lu, Y.-T., Li, M.-Y., Cheng, K.-T., Tan, C. M., Su, L.-W., Lin, W.-Y., et al. (2014). Transgenic plants that express the phytoplasma effector SAP11 show altered phosphate starvation and defense responses. Plant Physiol. 164, 1456-1469. doi: 10.1104/pp.113.229740

Luge, T., Kube, M., Freiwald, A., Meierhofer, D., Seemüller, E., and Sauer, S. (2014). Transcriptomics assisted proteomic analysis of Nicotiana occidentalis infected by Candidatus Phytoplasma mali strain AT. Proteomics 14, 1882-1889. doi: 10.1002/pmic.201300551

Ma, Y., Cao, J., He, J., Chen, Q., Li, X., and Yang, Y. (2018). Molecular mechanism for the regulation of $\mathrm{ABA}$ homeostasis during plant development and stress responses. Int. J. Mol. Sci. 19:3643. doi: 10.3390/ijms19113643

MacLean, A. M., Orlovskis, Z., Kowitwanich, K., Zdziarska, A. M., Angenent, G. C., Immink, R. G. H., et al. (2014). Phytoplasma effector SAP54 hijacks plant reproduction by degrading MADS-box proteins and promotes insect colonization in a RAD23-dependent manner. PLoS Biol. 12:e1001835. doi: 10.1371/journal.pbio.1001835

MacLean, A. M., Sugio, A., Makarova, O. V., Findlay, K. C., Grieve, V. M., Tóth, R., et al. (2011). Phytoplasma effector SAP54 induces indeterminate leaflike flower development in Arabidopsis plants. Plant Physiol. 157, 831-841. doi: $10.1104 / p p .111 .181586$

Maixner, M., and Reinert, W. (1999). Oncopsis alni (Schrank) (Auchenorrhyncha: Cicadellidae) as a vector of the alder yellows phytoplasma of Alnus glutinosa (L.) Gaertn. Eur. J. Plant Pathol. 105, 87-94. doi: 10.1023/A:1008602327715

Marcone, C. (2014). Molecular biology and pathogenicity of phytoplasmas. Ann. Appl. Biol. 165, 199-221. doi: 10.1111/aab.12151

Mardi, M., Karimi Farsad, L., Gharechahi, J., and Salekdeh, G. H. (2015). In-depth transcriptome sequencing of Mexican lime trees infected with 'Candidatus Phytoplasma aurantifolia'. PLoS ONE 10:e0130425. doi: 10.1371/journal.pone. 0130425

Margaria, P., Abbà, S., and Palmano, S. (2013). Novel aspects of grapevine response to phytoplasma infection investigated by a proteomic and phospho-proteomic approach with data integration into functional networks. BMC Genomics 14:38. doi: 10.1186/1471-2164-14-38

Margaria, P., and Palmano, S. (2011). Response of the Vitis vinifera L. cv. "Nebbiolo" proteome to Flavescence dorée phytoplasma infection. Proteomics 11, 212-224 doi: 10.1002/pmic.201000409

Mehle, N., Dermastia, M., Brus, R., and Jurc, D. (2017). First report of 'Candidatus Phytoplasma ulmi' in Ulmus minor and Ulmus glabra in Slovenia. Plant Dis. 101, 1819. doi: 10.1094/PDIS-02-17-0227-PDN

Miliordos, D. E., Galetto, L., Ferrari, E., Pegoraro, M., Marzachì, C., and Bosco, D. (2017). Acibenzolar- $S$-methyl may prevent vector-mediated flavescence dorée phytoplasma transmission, but is ineffective in inducing recovery of infected grapevines. Pest Manag. Sci. 73, 534-540. doi: 10.1002/ps.4303

Minato, N., Himeno, M., Hoshi, A., Maejima, K., Komatsu, K., Takebayashi, Y., et al. (2014). The phytoplasmal virulence factor TENGU causes plant sterility by downregulating of the jasmonic acid and auxin pathways. Sci. Rep. 4:7399. doi: 10.1038/srep07399

Monavarfeshani, A., Mirzaei, M., Sarhadi, E., Amirkhani, A., Khayam Nekouei, M., Haynes, P. A., et al. (2013). Shotgun proteomic analysis of the Mexican lime tree infected with 'Candidatus Phytoplasma aurantifolia'. J. Proteome Res. 12, 785-795. doi: 10.1021/pr300865t

Mur, L. A. J., Kenton, P., Atzorn, R., Miersch, O., and Wasternack, C. (2006). The outcomes of concentration-specific interactions between salicylate and jasmonate signaling include synergy, antagonism, and oxidative stress leading to cell death. Plant Physiol. 140, 249-262. doi: 10.1104/pp.105.072348

Musetti, R., Farhan, K., De Marco, F., Polizzotto, R., Paolacci, A., Ciaffi, M., et al. (2013). Differentially-regulated defence genes in Malus domestica. Eur. J. Plant Pathol. 136, 13-19. doi: 10.1007/s10658-012-0147-6 
Nejat, N., Cahill, D. M., Vadamalai, G., Ziemann, M., Rookes, J., and Naderali, N. (2015). Transcriptomics-based analysis using RNA-Seq of the coconut (Cocos nucifera) leaf in response to yellow decline phytoplasma infection. Mol. Genet. Genomics 290, 1899-1910. doi: 10.1007/s00438-015-1046-2

Nicolaisen, M., and Horvath, D. P. (2008). A branch-inducing phytoplasma in Euphorbia pulcherrima is associated with changes in expression of host genes. J. Phytopathol. 156, 403-407. doi: 10.1111/j.1439-0434.2007.01372.x

Oshima, K., Maejima, K., and Namba, S. (2013). Genomic and evolutionary aspects of phytoplasmas. Front. Microbiol. 4:230. doi: 10.3389/fmicb.2013.00230

Paolacci, A. R., Catarcione, G., Ederli, L., Zadra, C., Pasqualini, S., Badiani, M., et al. (2017). Jasmonate-mediated defence responses, unlike salicylate-mediated responses, are involved in the recovery of grapevine from bois noir disease. BMC Plant Biol. 17:118. doi: 10.1186/s12870-017-1069-4

Pieterse, C. M. J., Van der Does, D., Zamioudis, C., Leon-Reyes, A., and Van Wees, S. C. M. (2012). Hormonal modulation of plant immunity. Annu. Rev. Cell Dev. Biol. 28, 489-521. doi: 10.1146/annurev-cellbio-092910-154055

Prezelj, N., Covington, E., Roitsch, T., Gruden, K., Fragner, L., Weckwerth, W., et al. (2016a). Metabolic consequences of infection of grapevine (Vitis vinifera L.) cv. "Modra frankinja" with flavescence dorée phytoplasma. Front. Plant Sci. 7:711. doi: 10.3389/fpls.2016.00711

Prezelj, N., Fragener, L., Weckwerth, W., and Dermastia, M. (2016b). Metabolome of grapevine leaf vein-enriched tissue infected with 'Candidatus Phytoplasma solani'. Mitteilungen Klosterneubg Rebe und Wein Obs und Früchteverwertung 66, 74-78.

Prezelj, N., Nikolić, P., Gruden, K., Ravnikar, M., and Dermastia, M. (2013). Spatiotemporal distribution of flavescence dorée phytoplasma in grapevine. Plant Pathol. 62, 760-766. doi: 10.1111/j.1365-3059.2012.02693.x

Rijavec, T., and Dermastia, M. (2010). Cytokinins and their function in developing seeds. Acta Chim. Slov. 57, 617-629.

Robert-Seilaniantz, A., Grant, M., and Jones, J. D. G. (2011). Hormone crosstalk in plant disease and defense: more than just jasmonatesalicylate antagonism. Annu. Rev. Phytopathol. 49, 317-343. doi: 10.1146/annurev-phyto-073009-114447

Rotter, A., Nikolić, P., Turnšek, N., Kogovšek, P., Blejec, A., Gruden, K., et al. (2018). Statistical modeling of long-term grapevine response to 'Candidatus Phytoplasma solani' infection in the field. Eur. J. Plant Pathol. 150, 653-668. doi: 10.1007/s10658-017-1310-x

Santi, S., Grisan, S., Pierasco, A., De Marco, F., and Musetti, R. (2013). Laser microdissection of grapevine leaf phloem infected by stolbur reveals sitespecific gene responses associated to sucrose transport and metabolism. Plant Cell Environ. 36, 343-355. doi: 10.1111/j.1365-3040.2012.02577.x

Shao, F., Zhang, Q., Liu, H., Lu, S., and Qiu, D. (2016). Genome-wide identification and analysis of microRNAs involved in witches'-broom phytoplasma response in Ziziphus jujuba. PLoS ONE 11:e0166099. doi: 10.1371/journal.pone.0166099

Sheen, J. (2002). Phosphorelay and transcription control in cytokinin signal transduction. Science 296, 1650-1652. doi: 10.1126/science. 1071883

Shigenaga, A. M., and Argueso, C. T. (2016). No hormone to rule them all: interactions of plant hormones during the responses of plants to pathogens. Semin. Cell Dev. Biol. 56, 174-189. doi: 10.1016/J.SEMCDB.2016.06.005

Shigenaga, A. M., Berens, M. L., Tsuda, K., and Argueso, C. T. (2017). Towards engineering of hormonal crosstalk in plant immunity. Curr. Opin. Plant Biol. 38, 164-172. doi: 10.1016/j.pbi.2017.04.021

Shigeyuki, K., and Yasuko, Y. (2015). The role of genome sequencing in phytoplasma research. Phytopathog. Mollic. 5, 19-24. doi: 10.5958/2249-4677.2015.00058.4

Skalický, V., Kubeš, M., Napier, R., and Novák, O. (2018). Auxins and cytokininsthe role of subcellular organization on homeostasis. Int. J. Mol. Sci. 19:3115. doi: 10.3390/ijms19103115

Snyman, M. C., Solofoharivelo, M.-C., Souza-Richards, R., Stephan, D., Murray, S., and Burger, J. T. (2017). The use of high-throughput small RNA sequencing reveals differentially expressed microRNAs in response to aster yellows phytoplasma-infection in Vitis vinifera cv. "Chardonnay". PLoS ONE 12:e0182629. doi: 10.1371/journal.pone.0182629

Sugio, A., Kingdom, H. N., MacLean, A. M., Grieve, V. M., and Hogenhout, S. A. (2011a). Phytoplasma protein effector SAP11 enhances insect vector reproduction by manipulating plant development and defense hormone biosynthesis. Proc. Natl. Acad. Sci. U.S.A. 108, E1254-E1263. doi: $10.1073 /$ pnas. 1105664108
Sugio, A., MacLean, A. M., and Hogenhout, S. A. (2014). The small phytoplasma virulence effector SAP11 contains distinct domains required for nuclear targeting and CIN-TCP binding and destabilization. N. Phytol. 202, 838-848. doi: $10.1111 /$ nph.12721

Sugio, A., MacLean, A. M., Kingdom, H. N., Grieve, V. M., Manimekalai, R., and Hogenhout, S. A. (2011b). Diverse targets of phytoplasma effectors: from plant development to defense against insects. Annu. Rev. Phytopathol. 49, 175-195. doi: 10.1146/annurev-phyto-072910-095323

Sunkar, R., Li, Y.-F., and Jagadeeswaran, G. (2012). Functions of microRNAs in plant stress responses. Trends Plant Sci. 17, 196-203. doi: 10.1016/j.tplants.2012.01.010

Tai, C. F., Lin, C. P., Sung, Y. C., and Chen, J. C. (2013). Auxin influences symptom expression and phytoplasma colonisation in periwinkle infected with periwinkle leaf yellowing phytoplasma. Ann. Appl. Biol. 163, 420-429. doi: 10.1111/aab.12067

Tan, C. M., Li, C.-H., Tsao, N.-W., Su, L.-W., Lu, Y.-T., Chang, S. H., et al. (2016). Phytoplasma SAP11 alters 3-isobutyl-2-methoxypyrazine biosynthesis in Nicotiana benthamiana by suppressing NbOMT1. J. Exp. Bot. 67, 4415-4425. doi: 10.1093/jxb/erw225

Tan, P. Y., Whitlow, T., and Whitlow, T. (2001). Physiological responses of Catharanthus roseus (periwinkle) to ash yellows phytoplasmal infection. $N$ Phytol.150, 757-769. doi: 10.1046/j.1469-8137.2001.00121.x

Tang, J., Han, Z., and Chai, J. (2016). Q\&A: what are brassinosteroids and how do they act in plants? BMC Biol. 14:113. doi: 10.1186/s12915-016-0340-8

Tomkins, M., Kliot, A., Marée, A. F., and Hogenhout, S. A. (2018). A multilayered mechanistic modelling approach to understand how effector genes extend beyond phytoplasma to modulate plant hosts, insect vectors and the environment. Curr. Opin. Plant Biol. 44, 39-48. doi: 10.1016/J.PBI.2018.02.002

Tong, H., Xiao, Y., Liu, D., Gao, S., Liu, L., Yin, Y., et al. (2014). Brassinosteroid regulates cell elongation by modulating gibberellin metabolism in rice. Plant Cell 26, 4376-4393. doi: 10.1105/tpc.114.132092

Tsuda, K., Sato, M., Stoddard, T., Glazebrook, J., and Katagiri, F. (2009). Network properties of robust immunity in plants. PLoS Genet. 5:e1000772. doi: 10.1371/journal.pgen.1000772

Unterholzner, S. J., Rozhon, W., Papacek, M., Ciomas, J., Lange, T., Kugler, K. G., et al. (2015). Brassinosteroids are master regulators of gibberellin biosynthesis in Arabidopsis. Plant Cell 27, 2261-2272. doi: 10.1105/tpc.15.00433

Van Damme, M., Andel, A., Huibers, R. P., Panstruga, R., Weisbeek, P. J., and Van den Ackerveken, G. (2005). Identification of Arabidopsis loci required for susceptibility to the downy mildew pathogen Hyaloperonospora parasitica. Mol. Plant Microbe Interact. 18, 583-592. doi: 10.1094/MPMI-18-0583

Van Damme, M., Huibers, R. P., Elberse, J., and Van Den Ackerveken, G. (2008). Arabidopsis DMR6 encodes a putative 2OG-Fe(II) oxygenase that is defenseassociated but required for susceptibility to downy mildew. Plant J. 54, 785-793. doi: 10.1111/j.1365-313X.2008.03427.x

van Loon, L. C., Rep, M., and Pieterse, C. M. J. (2006). Significance of inducible defense-related proteins in infected plants. Annu. Rev. Phytopathol. 44, 135-162. doi: 10.1146/annurev.phyto.44.070505.143425

van Wees, S. C., de Swart, E. A., van Pelt, J. A., van Loon, L. C., and Pieterse, C. M. (2000). Enhancement of induced disease resistance by simultaneous activation of salicylate- and jasmonate-dependent defense pathways in Arabidopsis thaliana. Proc. Natl. Acad. Sci. U.S.A. 97, 8711-8716. doi: 10.1073/pnas.130425197

Wang, H., Ye, X., Li, J., Tan, B., Chen, P., Cheng, J., et al. (2018). Transcriptome profiling analysis revealed co-regulation of multiple pathways in jujube during infection by 'Candidatus Phytoplasma ziziphi'. Gene 665, 82-95. doi: 10.1016/j.gene.2018.04.070

Wasternack, C. (2015). How jasmonates earned their laurels: past and present. J. Plant Growth Regul. 34, 761-794. doi: 10.1007/s00344-015-9526-5

Wasternack, C., and Song, S. (2016). Jasmonates: biosynthesis, metabolism, and signaling by proteins activating and repressing transciption. J. Exp. Bot. 68:erw443. doi: 10.1093/jxb/erw443

Wasternack, C., and Strnad, M. (2019). Jasmonates are signals in the biosynthesis of secondary metabolites - Pathways, transcription factors and applied aspects - A brief review. N. Biotechnol. 48, 1-11. doi: 10.1016/j.nbt.201 7.09.007

Wei, Z., Wang, Z., Li, X., Zhao, Z., Deng, M., Dong, Y., et al. (2017). Comparative proteomic analysis of Paulownia fortunei response to phytoplasma 
infection with dimethyl sulfate treatment. Int. J. Genomics 2017, 1-11. doi: 10.1155/2017/6542075

Weijers, D., Nemhauser, J., and Yang, Z. (2018). Auxin: small molecule, big impact. J. Exp. Bot. 69, 133-136. doi: 10.1093/jxb/erx463

White, R. F. (1979). Acetylsalicylic acid (aspirin) induces resistance to tobacco mosaic virus in tobacco. Virology 99, 410-412.

Wu, Y., Zhang, D., Chu, J. Y., Boyle, P., Wang, Y., Brindle, I. D., et al. (2012). The Arabidopsis NPR1 protein is a receptor for the plant defense hormone salicylic acid. Cell Rep. 1, 639-647. doi: 10.1016/j.celrep.2012.05.008

Yan, C., and Xie, D. (2015). Jasmonate in plant defence: sentinel or double agent? Plant Biotechnol. J. 13, 1233-1240. doi: 10.1111/pbi.12417

Ye, X., Wang, H., Chen, P., Fu, B., Zhang, M., Li, J., et al. (2017). Combination of iTRAQ proteomics and RNA-seq transcriptomics reveals multiple levels of regulation in phytoplasma-infected Ziziphus jujuba Mill. Hortic. Res. 4:17080. doi: 10.1038/hortres.2017.80

Youssef, S. A., Safwat, G., Shalaby, A. B. A., and El-Beltagi, H. S. (2018). Effect of phytoplasma infection on plant hormones enzymes and their role in infected sesame. Fresenius Environ. Bull. 27, 5727-5735.

Zeilmaker, T., Ludwig, N. R., Elberse, J., Seidl, M. F., Berke, L., Van Doorn, A., et al. (2015). DOWNY MILDEW RESISTANT 6 and DMR6-LIKE OXYGENASE 1 are partially redundant but distinct suppressors of immunity in Arabidopsis. Plant J. 81, 210-222. doi: 10.1111/tpj.12719

Zemlyanskaya, E. V., Omelyanchuk, N. A., Ubogoeva, E. V., and Mironova, V. V. (2018). Deciphering auxin-ethylene crosstalk at a systems level. Int. J. Mol. Sci. 19:4060. doi: 10.3390/ijms19124060
Zhang, W., Gao, S., Zhou, X., Chellappan, P., Chen, Z., Zhou, X., et al. (2011). Bacteria-responsive microRNAs regulate plant innate immunity by modulating plant hormone networks. Plant Mol. Biol. 75, 93-105. doi: $10.1007 /$ s11103-010-9710-8

Zhang, W., Zhao, F., Jiang, L., Chen, C., Wu, L., and Liu, Z. (2018). Different pathogen defense strategies in Arabidopsis: more than pathogen recognition. Cells 7:252. doi: 10.3390/cells7120252

Zhang, Y., Zhao, L., Zhao, J., Li, Y., Wang, J., Guo, R., et al. (2017). S5H/DMR6 encodes a salicylic acid 5-hydroxylase that fine-tunes salicylic acid homeostasis. Plant Physiol. 175, 1082-1093. doi: 10.1104/pp.17.00695

Zhong, B.-X., and Shen, Y.-W. (2004). Accumulation of pathogenesis-related type-5 like proteins in phytoplasma-infected garland chrysanthemum Chrysanthemum coronarium. Acta Biochim. Biophys. Sin. 36, 773-779. doi: $10.1093 /$ abbs/36.11.773

Conflict of Interest Statement: The author declares that the research was conducted in the absence of any commercial or financial relationships that could be construed as a potential conflict of interest.

Copyright (c) 2019 Dermastia. This is an open-access article distributed under the terms of the Creative Commons Attribution License (CC BY). The use, distribution or reproduction in other forums is permitted, provided the original author(s) and the copyright owner(s) are credited and that the original publication in this journal is cited, in accordance with accepted academic practice. No use, distribution or reproduction is permitted which does not comply with these terms. 